\title{
Collagen stimulating factors in hepatic fibrogenesis
}

\author{
A FALLON, * JF BRADLEY, J BURNS, J O'D McGEE \\ From the University of Oxford, Nuffield Department of Pathology, John Radcliffe Hospital, Oxford
}

SUMMARY Four factors which stimulate collagen synthesis and prolyl hydroxylase activity in cultures of human and mouse fibroblasts have been isolated by molecular sieve chromatography from animal and human fibrotic and cirrhotic livers. These factors do not stimulate protein or DNA synthesis or total DNA in these cultures. It has also been shown that these factors, designated collagen stimulating factors $\mathrm{F} 1-\mathrm{F} 4$, do not owe their activity to ascorbate or glutamine. Collagen stimulating factors are heat stable, and F1 and F2 have apparent molecular weights of about 4000 and 1000 respectively. Since these factors are not present in normal animal or human liver it is suggested that they may be responsible for increased collagen production in vivo in hepatic fibrosis and cirrhosis.

The collagen content of the liver increases four to five fold in hepatic cirrhosis. ${ }^{1}$ This is at least partially due to an increase in collagen synthesis in those diseases which progress to cirrhosis. ${ }^{23}$ Collagen deposition in the form of fibrous septa leads to disorganisation of the microanatomy of the liver, intrahepatic shunting, and portal hypertension. Its accumulation in the space of Disse may also interfere with metabolic exchanges between the sinusoidal vascular compartment and the microvillous surface of the hepatocyte. $^{3}$

In experimental hepatic fibrosis a group of low molecular weight compounds, collagen stimulating factors, have been isolated which stimulate collagen synthesis and prolyl hydroxylase (EC: 1.14.11.2) activity in fibroblasts in vitro. ${ }^{24}$ Prolyl hydroxylase catalyses the biosynthesis of hydroxyproline, which is necessary for the formation of a stable collagen triple helix.

We have shown that collagen stimulating factors are present in human cirrhotic liver as well as in experimental liver disease but not in normal liver. We have also shown that they stimulate collagen synthesis specifically and that they differ in their physicochemical and biological properties from other compounds which have been postulated to modulate collagen synthesis in liver disease.

*Present address: Searle Research Laboratories, Lane End Road, High Wycombe, Bucks UK.

Accepted for publication 7 December 1983

\section{Material and methods}

All chemicals, of the highest purity obtainable, were purchased from British Drug Houses, Poole, Dorset, or Sigma Chemical Co Ltd, London; all radioisotopes were obtained from the Radiochemical Centre, Amersham; scintillation fluid was obtained from Nuclear Enterprises, Sighthill, Edinburgh; and all reagents for tissue culture and cells were obtained from Gibco Biocult, Paisley, Scotland.

\section{ISOLATION OF COLLAGEN STIMULATING FACTORS}

Collagen stimulating factors were isolated from murine liver by a modification of a method described earlier. ${ }^{2}$ Acute liver damage was produced in male albino mice (strain CFLP) weighing roughly $20 \mathrm{~g}$. A single dose $(0.25 \mathrm{ml})$ of a $40 \%$ solution of carbon tetrachloride in liquid paraffin was administered by oesophageal tube. Three days later six animals were killed by cervical dislocation and the livers were removed. After excision of the gall bladder, the livers were placed on ice and all subsequent operations were performed at $4^{\circ} \mathrm{C}$. The tissue was chopped finely with scissors and homogenised in 2.5 volumes ( $\mathrm{wt} / \mathrm{vol}$ ) of ice cold $0.05 \mathrm{M}$ sodium phosphate buffer $\mathrm{pH} 7.0$ containing $10^{-3} \mathrm{M}$ dithiothreitol, $10^{-4} \mathrm{M}$ edetic acid, and $0.15 \mathrm{M} \mathrm{NaCl}$ (homogenisation buffer) in a close fitting ground glass homogeniser. The homogenate was centrifuged at $10000 \mathrm{~g}$ for $30 \mathrm{~min}$ and the supernatant, minus the lipid layer, was heated at $56^{\circ} \mathrm{C}$ for $20 \mathrm{~min}$ 542 
in a polypropylene vial and centrifuged for a further $30 \mathrm{~min}$ at $10000 \mathrm{~g}$. The supernatant was passed through a glass column $(90 \times 2.5 \mathrm{~cm})$ of $\mathrm{G} 25$ Sephadex equilibrated in homogenisation buffer. The column was eluted with the same buffer and 12 $\mathrm{ml}$ fractions were collected at a flow rate of $30 \mathrm{ml} /$ hour at $4^{\circ} \mathrm{C}$. The absorbance of each fraction was monitored at $280 \mathrm{nM}$ and selected fractions were assayed for their ability to stimulate collagen biosynthesis and prolyl hydroxylase activity in L-929 cultures.

Collagen stimulating factors were isolated from human liver with slight modifications of the above procedure. Liver biopsy specimens from a patient with alcoholic cirrhosis $(2.5 \mathrm{~g})$ and from a patient without clinical or biochemical evidence of liver disease $(1.8 \mathrm{~g})$ were obtained at laparotomy for these experiments. Collagen stimulating factors were extracted as above in 5 volumes (wt/vol) of homogenisation buffer, applied to a G25 Sephadex column $(70 \times 1.5 \mathrm{~cm})$, and eluted with homogenisation buffer, and $6 \mathrm{ml}$ fractions were collected. Collagen stimulating factor activity was assayed by monitoring prolyl hydroxylase activity in human lung fibroblasts (W1-38 cells).

\section{COLLAGEN SYNTHESIS IN CELL CULTURES}

Mouse skin fibroblasts (cell line L-929) were grown in $120 \mathrm{~cm}^{2}$ glass flasks in $25 \mathrm{ml}$ of minimal essential medium buffered with $20 \mathrm{mM}$ Hepes containing Earles salts, $10 \%$ fetal calf serum, $2 \times 10^{-3} \mathrm{M}$ sodium-L-ascorbate, $4 \times 10^{-6} \mathrm{M}$ ferric nitrate, $2 \times$ $10^{-3} \mathrm{M}$ L-glutamine, and $50 \mathrm{units} / \mathrm{ml}$ of penicillin/ streptomycin and incubated under air at $37^{\circ} \mathrm{C}$. For assay of collagen synthesis the cells were harvested from stock bottles by addition of $0.025 \%$ trypsin; after counting they were seeded at $0.4 \times 10^{5} / \mathrm{cm}^{2}$ in $25 \mathrm{~cm}^{2}$ plastic Falcon flasks in $5 \mathrm{ml}$ of the same medium.

Cells were grown for $40 \mathrm{~h}$ before exposure to selected fractions of column effluents. Aliquots (1 $\mathrm{ml}$ ) of the latter were added to the culture for $5 \mathrm{~h}$ and then each culture was pulsed for $1 \mathrm{~h}$ with $10 \mu \mathrm{Ci}$ of $3,4{ }^{3} \mathrm{H}$-proline (SA $40 \mathrm{Ci} / \mathrm{mmol}$ ) before harvesting. After removal of medium the cell layer was washed twice with $1 \mathrm{ml}$ of $0.15 \mathrm{M} \mathrm{NaCl}$ and the cells scraped from the flask and resuspended to $10 \% / \mathrm{ml}$ in $0.05 \mathrm{M}$ Tris buffer $\mathrm{pH} \mathrm{7.6}$. The cells were then disrupted by sonication and an aliquot $(0.5 \mathrm{ml})$ digested with $20 \mu \mathrm{g} / \mathrm{ml}$ of RNase for $10 \mathrm{~min}$ at $30^{\circ} \mathrm{C}$ to remove any radioactive prolyl t-RNA. An equal volume of $20 \%$ trichloroacetic acid (TCA) was added to precipitate protein and the mix was allowed to stand at $4^{\circ} \mathrm{C}$ for $20 \mathrm{~min}$. The pellet was separated by centrifugation at $3000 \mathrm{~g}$ for $10 \mathrm{~min}$ and washed a further five times in 5\% TCA before being solubilised in $0.1 \mathrm{M} \mathrm{NaOH}$. The sample was then divided into two aliquots of $0.2 \mathrm{ml}$ and incubated in a reaction mix containing the following: $0.1 \mathrm{ml}$ of $\mathrm{N}$-ethylmalemide, $5 \mu \mathrm{l}$ of $0.05 \mathrm{M}$ calcium chloride, 10-20 $\mu$ l of purified bacterial collagenase, and water to a final volume of $0.5 \mathrm{ml}$; control tubes contained $0.2 \mathrm{ml}$ of solubilised cell pellet and all other reagents but no collagenase. ${ }^{5}$ Samples were incubated at $37^{\circ} \mathrm{C}$ for $60 \mathrm{~min}$ and the reaction was terminated by adding $0.5 \mathrm{ml}$ of $0.5 \%$ tannic acid in $10 \%$ TCA. After incubation at $4^{\circ} \mathrm{C}$ for $30 \mathrm{~min}$ the samples were centrifuged at $3000 \mathrm{~g}$ for $15 \mathrm{~min}$. Radioactive collagen peptides in the supernatant were measured by liquid scintillation counting in NE260 scintillant. The collagenase used in this assay was repurified before use and degraded only collagenous proteins. ${ }^{5}$

\section{PROTEIN SYNTHESIS IN CELL CULTURES}

An aliquot of cell sonicate prepared as described above was digested with RNase and then spotted on to a filter paper disc (Whatmann 3MM) and allowed to dry. The disc was immersed in $20 \%$ TCA for 20 min followed by sequential washings in $10 \%$ and 5\% TCA and finally extracted into ether and allowed to dry. The disc was then placed in $10 \mathrm{ml}$ of Brays solution and counted.

PROLYL HYDROXYLASE IN CELL CULTURES AND HUMAN LIVER

L-929 cells or W1-38 (human) fibroblasts, grown as described above, were seeded at $0.2 \times 10^{4} / \mathrm{cm}^{2}$ in 25 $\mathrm{cm}^{2}$ Falcon flasks and incubated for $40 \mathrm{~h}$ before the addition of collagen stimulating factors. The cultures were then incubated for $6 \mathrm{~h}$. After discarding the medium the cell layer was washed twice with $1 \mathrm{ml}$ of saline and the cells were removed mechanically into $1 \mathrm{ml}$ of saline. The cells were suspended to $10 \% \mathrm{ml}$ in $0.25 \mathrm{M}$ sucrose containing $10^{-4} \mathrm{M}$ dithiothreitol and $10^{-5} \mathrm{M}$ edetic acid, sonicated, and an aliquot assayed for prolyl hydroxylase activity using the tritium release assay. ${ }^{6}$ L-929 cells and W1-38 fibroblasts were used for assay of mouse and human collagen stimulating factors respectively.

Prolyl hydroxylase activity in human liver was measured as described previously. ${ }^{3}$

\section{DNA SYNTHESIS IN CELL CULTURES}

Total DNA in fibroblast cultures was measured by the method of Burton.' DNA synthesis in cultured cells was measured by the incorporation of ${ }^{3} \mathrm{H}$ deoxyribose thymidine $(\mathrm{SA} 7 \cdot 6 \mathrm{Ci} / \mathrm{mmol})$ into acid precipitable nucleic acid. Cultures were incubated with collagen stimulating factors for $6-48 \mathrm{~h}$ and then pulsed for $1 \mathrm{~h}$ with ${ }^{3} \mathrm{H}$ thymidine before harvesting. After washing the cell pellet in $0.1 \mathrm{M} \mathrm{NaCl}$ the cultures were extracted with $2 \%$ perchloroacetic acid at 
$60^{\circ} \mathrm{C}$, and $0 \cdot 1 \mathrm{ml}$ of the supernatant was counted in $10 \mathrm{ml}$ of NE270 scintillant.

\section{ASSAY OF ASCORBIC ACID IN G25 SEPHADEX COLUMN EFFLUENTS}

For estimating ascorbic acid in column fractions the columns were run in buffer without dithiothreitol or edetic acid. This had no effect on the activity of collagen stimulating factors; these reagents may play some role in the temporal stabilisation of collagen stimulating factors. Ascorbic acid was detected by the method of Zannoni et al. ${ }^{8}$ This assay is based on the ability of ascorbic acid to reduce $\mathrm{Fe}^{3+}$ to $\mathrm{Fe}^{2+}$, which, when coupled to $\alpha, \alpha^{1}$-dipyridyl, produces a colorimetric reaction. Column effluent $(1 \mathrm{ml})$ was mixed with $0.5 \mathrm{ml}$ of $15 \%$ TCA and the precipitate was spun out at $3000 \mathrm{~g}$. The supernatant was added to a mix containing the following: $0.1 \mathrm{ml}$ of $85 \%$ orthophosphoric acid, $0.8 \mathrm{ml}$ of $10 \%$ aqueous $\alpha$, $\alpha^{1}$-dipyridyl, and $0.1 \mathrm{ml}$ of ferric chloride in a final volume of $2.5 \mathrm{ml}$. All reagents were freshly prepared for each experiment. Sodium-l-ascorbate was used as a standard. The colorimetric reaction was developed at room temperature for $30 \mathrm{~min}$ and absorbance was read at $430 \mathrm{nM}$.

\section{IMMUNOHISTOCHEMICAL LOCALISATION OF} COLLAGEN IN MOUSE LIVER

Sheep antiserum to acetic acid soluble rat collagen was prepared as described previously. ${ }^{9}$ The anticollagen antibody in this serum was purified by affinity chromatography on a column of rat type I collagen linked to cyanogen bromide Sepharose 6B.9 The purified antibody reacted equally well with type $I$ and type III collagen. Blocks 3-4 $\mu \mathrm{m}$ thick were taken from mouse liver and rapidly frozen on to microtome chucks. Sections from normal mouse liver and mouse liver damaged by carbon tetrachloride were cut at $-20^{\circ} \mathrm{C}$ and placed on glass slides. The slides were washed with $0.01 \mathrm{M}$ phosphate buffer $\mathrm{pH} 7.2$ containing $0.15 \mathrm{M} \mathrm{NaCl}$ (PBS), $20 \%$ normal swine serum, and incubated in the same solution for 5-10 min. Slides were dried and treated with anticollagen antibody $(100 \mu \mathrm{g} \mathrm{IgG} / \mathrm{ml})$ for 30 min at room temperature. Sections were washed three times for 4 min in three changes of PBS and treated with rabbit antigoat fluorescent antibody (Dakopatts) for $30 \mathrm{~min}$ at room temperature; the antigoat antibody, which cross reacts with sheep IgG, was diluted $1 / 30$ in PBS. After a further three washes in PBS, the sections were mounted in $90 \%$ glycerol/PBS and viewed under ultraviolet light. Control sections were treated with normal sheep IgG $(100 \mu \mathrm{g} / \mathrm{ml})$ followed by fluorescein labelled rabbit antigoat serum or with the latter reagent alone.

\section{Results}

In normal liver the anticollagen antibody reacted with the collagen around central and portal veins and with sinusoidal fibres (Fig. 1a). Three days after carbon tetrachloride injury there was a considerable increase in collagen around the central zones of the

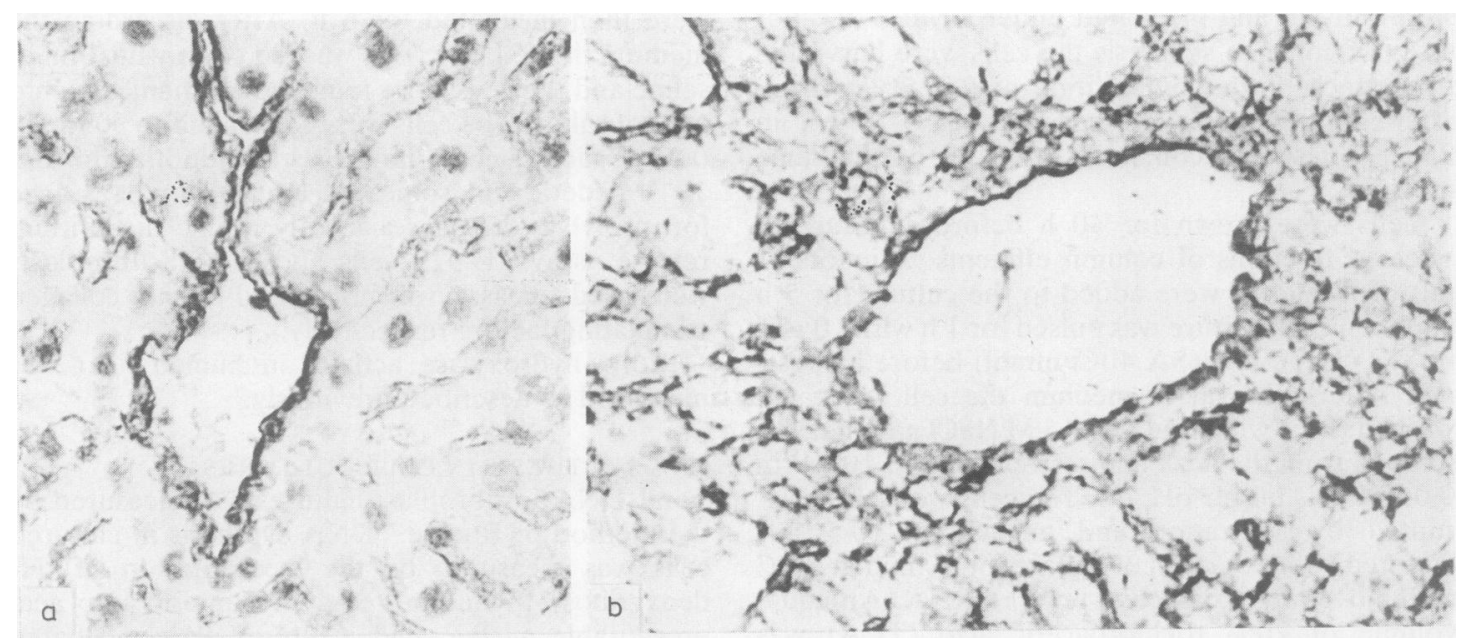

Fig. 1 (a) Distribution of collagen in normal mouse liver determined by antibody which reacts with type I and III collagen. Collagen is present around the central (effuent) vein and along sinusoids. (b) Immunohistochemical localisation of collagen in mouse liver three days after treatment with carbon tetrachloride. Collagen deposition is increased in the healing centrilobular zone of liver around a central vein. 
lobuie where hepatocyte debris was being resorbed (Fig. 1b). Normal and carbon tetrachloride damaged liver treated with normal sheep IgG or second fluorescent antibody did not react with liver collagen.

Factors which stimulated collagen synthesis in L-929 fibroblasts were detected in extracts of mouse liver three days after carbon tetrachloride injury but not in extracts of normal mouse liver. When extracts of damaged liver were chromatographed on G25 Sephadex, four factors were isolated (Fig. 2). These factors were designated F1-F4. F1 stimulated collagen synthesis 5.7 fold, F2 6.3 fold, F3 4.7 fold, and F4 4 fold. Fig. 3 shows that these same fractions stimulated total protein synthesis to the following extent: F1 1.4 fold, F2 2.6 fold, F3 1.9 fold, and F4 $2 \cdot 1$ fold. By comparison, chromatograms of normal liver extracts showed only one area (between fractions 30 and 45) which stimulated collagen synthesis 2.3 times (Fig. 2). The latter fractions also stimu-

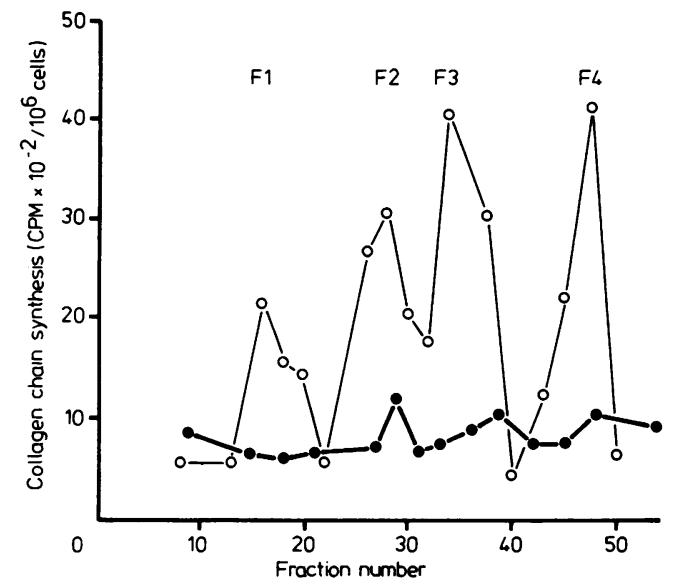

Fig. 2 Stimulation of collagen synthesis by fractions from a G25 Sephadex column prepared from a heated supernatant of carbon tetrachloride damaged liver $\mathrm{O}-\mathrm{O}$ and from a normal liver - Selected fractions were added to replicate cultures of $L-929$ fibroblasts and the cultures assayed for collagen synthesis as described in Materials and methods section. CPM = counts per minute.

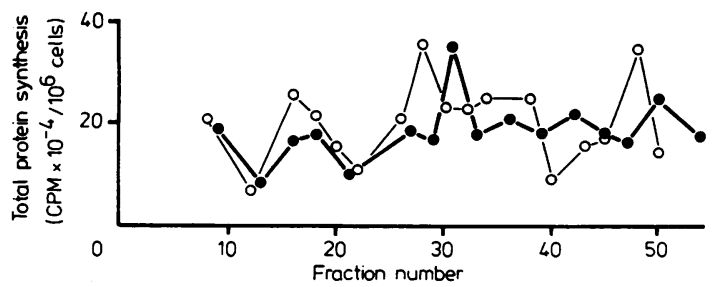

Fig. 3 Effect of fractions from a G25 chromatogram of normal liver -1 and damaged liver $\mathrm{O}-\mathrm{O}$ on protein synthesis. lated protein synthesis up to a maximum of $2 \cdot 3$ times (Fig. 3) that of controls-in other words, these fractions from normal liver have the same effect on collagen and total protein synthesis. The results shown in Figs. 2 and 3 are representative of over 200 experiments.

Fractions from G25 chromatograms of damaged and normal mouse liver were assayed for their ability to stimulate prolyl hydroxylase activity in mouse fibroblasts. As shown in Fig. 2, F1, F2, F3, and F4 increased prolyl hydroxylase activity in these cells $15 \cdot 8,10 \cdot 5,4 \cdot 5$, and 7 fold respectively. It should be noted that those fractions which increased hydroxylase activity also stimulated collagen synthesis (see Fig. 2). By contrast, column effluent in the F1 and F2 regions from normal liver stimulated hydroxylase activity 1.4 and 2.5 fold respectively; material eluting in the F3 and F4 region in normal liver chromatograms did not stimulate the activity of this enzyme. The data shown in Fig. 4 are representative of more than 20 experiments in which the maximum stimulation of prolyl hydroxylase activity by F1 from damaged liver was up to 20 fold; the maximum observed with F2 from normal liver being 4 fold.

None of the factors from damaged liver (and the effluent from normal liver columns) had cytotoxic activity for L-929 cells as assessed by trypan blue exclusion. The cytotoxic activity of F1 from damaged liver reported earlier ${ }^{2}$ is abolished by heating liver extracts at $56^{\circ} \mathrm{C}$ before chromatography.

Normal human and alcoholic cirrhotic liver were examined for the presence of collagen stimulating factors by molecular sieve chromatography of crude

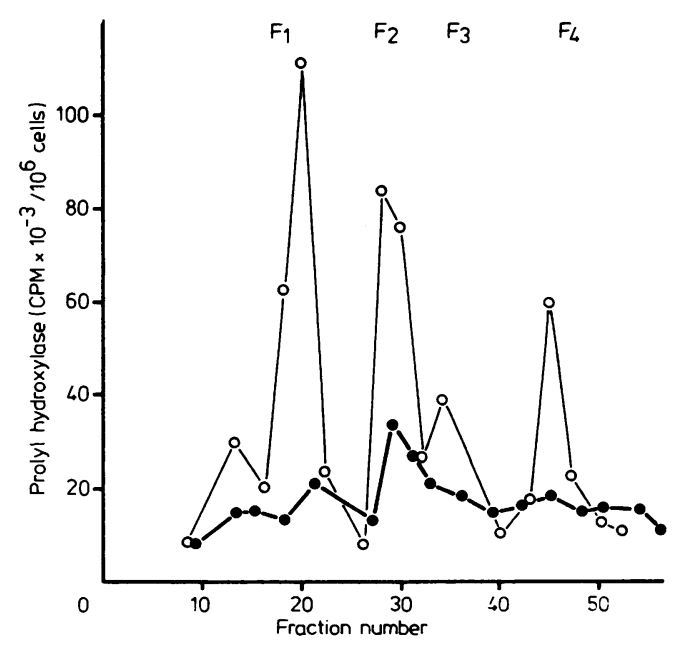

Fig. 4 Prolyl hydroxylase activity in replicate L-929 cultures treated with selected fractions from a G25 chromatogram of damaged $\mathrm{O}-\mathrm{O}$ and normal liver -0. 
liver extracts. Since there was coincidence of stimulation of collagen synthesis and prolyl hydroxylase in fractions from mouse liver damaged by carbon tetrachloride the column effluents from human material were assayed for collagen stimulating factors by examining their effect on prolyl hydroxylase activity in human fibroblasts (W138). The enzyme assay is at least five times less time consuming than that for collagen synthesis; this is important in isolating collagen stimulating factors since they are labile. As shown in Fig. 5, human cirrhotic liver contained four collagen stimulating factors; F1, F2, F3, and F4 from human cirrhotic liver stimulated prolyl hydroxylase activity $1 \cdot 7,2 \cdot 6,2 \cdot 3$, and 2 fold respectively whereas the same fractions from normal liver had no appreciable effect on this enzyme. Homogenates of the cirrhotic liver used in this experiment had a prolyl hydroxylase level four times that of the normal liver used, indicating that there was active fibroplasia in the cirrhotic liver. ${ }^{3}$

Prolyl hydroxylase activity in fibroblasts is increased by exposure to ascorbate and lactate." Ascorbate eluted from G25 columns in the F2 region (data not shown). In damaged and normal mouse liver chromatograms, ascorbate was present at a concentration of $20-70 \mu \mathrm{g} / \mathrm{ml}$ and $15-50 \mu \mathrm{g} / \mathrm{ml}$ respectively in the $F 2$ region only. To check whether the increase in prolyl hydroxylase activity by F2 from damaged liver was due to ascorbate, the sensitivity of F2 to cuprous ion was tested; cuprous ion destroys ascorbate. ${ }^{7}$ Table 1 shows that when F2 from injured liver was treated with cuprous chloride

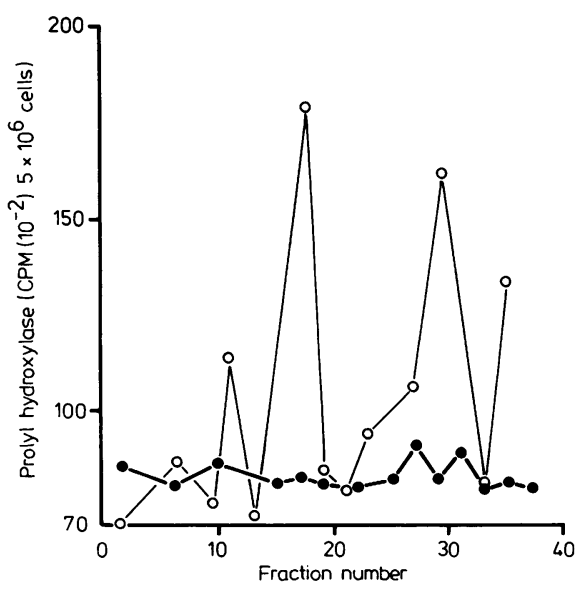

Fig. 5 Prolyl hydroxylase activity in W1-38 fibroblasts treated with selected fractions $(1 \mathrm{ml}$ aliquots) from $\mathrm{G} 25$ chromatograms of human alcoholic cirrhotic $\Delta-\Delta$ and normal liver - Absorbance at $280 \mathrm{mM}$ of fractions from the cirrhotic and normal liver column were roughly equal (not shown).
Table 1 Effect of F2 and ascorbate on prolyl hydroxylase activity

\begin{tabular}{lll}
\hline Additions & $\begin{array}{l}\text { Cuprous chloride } \\
(0.1 \mathrm{mM})\end{array}$ & $\begin{array}{l}\text { Prolyl hydroxylase activity } \\
\left(\mathrm{CPM} \times 10^{-3} / 10^{\circ} \text { cells }\right)\end{array}$ \\
\hline Buffer & - & 5.6 \\
& + & 5.8 \\
F2 & - & 17.6 \\
Ascorbate & + & 15.6 \\
$(5 \mu \mathrm{M})$ & + & 20.6 \\
\hline
\end{tabular}

Cuprous chloride (0-1 $\mathrm{mM}$ final concentration) was added to F2 from carbon tetrachloride damaged liver and to sodium-1ascorbate; $95 \% \mathrm{O}, 5 \% \mathrm{CO}$, was bubbled through the mixtures for $30 \mathrm{~s}$. Samples $(1 \mathrm{ml})$ were then added to cultures for $6 \mathrm{~h}$ and these cultures were then assayed for prolyl hydroxylase. The concentration of ascorbate used in the experiment was the same as that found in $\mathbf{F} 2$.

$\mathbf{C P M}=$ counts per minute.

Table 2 Effect of free ascorbate and F2 on collagen and protein synthesis

\begin{tabular}{lcl}
\hline Additions & $\begin{array}{l}\text { Collagen synthesis } \\
\left(C P M \times 10^{-2} / 10^{6} \text { cells }\right)\end{array}$ & $\begin{array}{l}\text { Protein synthesis } \\
\left(C P M \times 10^{-4} / 10^{\circ} \text { cells }\right)\end{array}$ \\
\hline Nil & 6.0 & 6.8 \\
Buffer & 5.5 & 7.9 \\
Ascorbate & 5.8 & $7 \cdot 0$ \\
F2 & 18.7 & 8.2 \\
\hline
\end{tabular}

F2 (1 ml) from a G25 chromatogram of damaged mouse liver and free ascorbate were added to replicate cultures of L-929 fibroblasts and each culture assayed for collagen synthesis. The concentration of ascorbate used was the same as that found in F2 - that is, a final concentration in cultures of $8 \mu \mathrm{M}$. The results are the mean of two separate estimations.

$\mathrm{CPM}=$ counts per minute .

it retained its activity whereas the ability of ascorbate to stimulate prolyl hydroxylase was inactivated by the copper. Material eluted in the F2 frorn normal liver, which stimulated prolyl hydroxylase, was also destroyed by cuprous chloride. Table 2 shows that ascorbate had no effect on collagen synthesis in L-929 fibroblasts while collagen stimulating factor 2 from damaged liver stimulated collagen synthesis up to 5 times that of control cultures (Fig. 2); the F2 region from normal liver did not stimulate collagen synthesis. Lactate was not present in the effluent from either normal or damaged liver extracts (data not shown). Neither ascorbate or lactate, therefore, are responsible for prolyl hydroxylase stimulation in collagen stimulating factors from diseased livers.

Recently Ronnema et al $^{10}$ isolated a factor from liver which stimulated collagen synthesis; this was identified as glutamine. The effect of glutamine on collagen synthesis and protein synthesis was therefore tested in L-929 cultures (Fig. 6). Glutamine $\left(10^{-5} \mathrm{M}\right)$ increased collagen synthesis 1.7 times and protein synthesis 1.3 times. Higher concentrations of glutamine resulted in inhibition of both collagen and protein synthesis. 


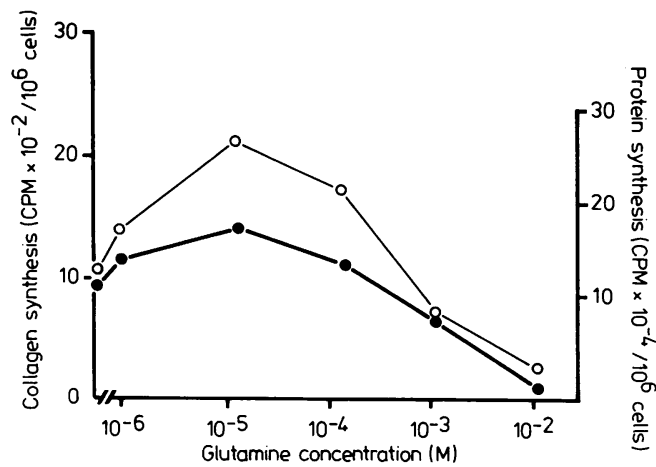

Fig. 6 Effect of various concentrations of L-glutamine on collagen synthesis and total protein synthesis in L-929 fibroblast cultures. Fibroblast cultures were grown for $40 \mathrm{~h}$ as described in Materials and methods section. The initial concentration of glutamine in the culture medium at the time of plating was $2 \times 10^{-3} \mathrm{M}$. Further glutamine was added to replicate cultures at the concentrations indicated and incubated for a further $6 \mathrm{~h}$. The cultures were then harvested and assayed for collagen synthesis $\mathrm{O}-\mathrm{O}$ and protein synthesis - as described.

To determine the molecular weight of collagen stimulating factors the G25 column used for their isolation was calibrated with markers of known molecular weight. From the elution volumes of the latter we calculated that the F1 has a molecular weight of about 4000 and F2 1000 (data not shown). Determination of the molecular weight of F3 and F4 was outside the resolution of the column since both were adsorbed on to the Sephadex matrix.

Table 3 shows the effect of collagen stimulating factors F1 and F2 from carbon tetrachloride damaged liver on the uptake of tritiated thymidine in L-929 cultures. The rate of uptake decreased with time as the cells grew to confluence but there was no difference between those cultures treated with F1 and $\mathrm{F} 2$ and the corresponding controls. In addition,

Table 3 Effect of $F 1$ and $F 2$ on DNA synthesis

\begin{tabular}{llcc}
\hline Additions & \multicolumn{3}{l}{$\begin{array}{l}\text { DNA synthesis after exposure to collagen } \\
\text { stimulating factors } \\
\text { (CPM } \times 10^{-4 / \mu g} \text { DNA) }\end{array}$} \\
\cline { 2 - 4 } & $6 h$ & $24 h$ & $48 h$ \\
\hline Nil & 4.5 & 2.5 & 1.6 \\
Buffer & 4.8 & 2.8 & 1.9 \\
F1 & 5.0 & 2.8 & 2.0 \\
Nil & 4.6 & 2.9 & 1.9 \\
Buffer & 3.8 & 3.0 & 1.6 \\
F2 & 4.5 & 3.2 & 1.8 \\
\hline
\end{tabular}

$F 1$ and $F 2(1 \mathrm{ml})$ from damaged liver or buffer were added to replicate cultures of L-929 fibroblasts $16 \mathrm{~h}$ after plating. The cultures were harvested at the times indicated after these additions. Before harvesting, each culture was pulsed for one hour with ${ }^{3} \mathrm{H}$ deoxyribose thymidine and the incorporation of this isotope into DNA measured as described in Materials and methods section. the factors had no effect on total cell number or total DNA (data not shown).

\section{Discussion}

It has been shown previously that in response to acute carbon tetrachloride poisoning in mice there is an increase in collagen synthesis in the liver. ${ }^{2}$ This model of fibrosis has been used to study the control mechanisms of collagen synthesis. As shown in Figs. $1 \mathrm{a}$ and $1 \mathrm{~b}$ collagen fibres are deposited in the liver parenchyma three days after injury in the areas surrounding the central vein and in the areas of tissue repair. Similar observations have been made in rats subjected to prolonged carbon tetrachloride poisoning. ${ }^{1}$

Using this model we have shown that there is a group of low molecular weight factors in these livers which specifically stimulate collagen synthesis when added to cultured fibroblasts. Similar factors have also been found in healing wounds. ${ }^{12}$ Moreover, they are also present in the liver of a patient with alcoholic cirrhosis and not in normal human liver. It is therefore proposed that these factors may be the mediators of increased collagen synthesis in hepatic fibrosis in both animals and man.

A prominent feature of hepatic fibrosis is the presence in the parenchyma of mononuclear cell types such as macrophages and lymphocytes. Also notable is the increase in the number of fibroblasts. These observations have prompted workers to look for the existence of lymphokines which increase the number of collagen producing cells. One report $^{13}$ showed evidence of a lymphokine that was released from mitogen stimulated peripheral blood lymphocytes and another report showed evidence of a $\mathrm{T}$ cell dependent factor that stimulated fibroblast growth. ${ }^{14}$ Wyler et $a^{15}$ also presented evidence that a lymphokine could be responsible for the increased fibroblast content in the livers of mice with experimentally induced schistosomiasis. ${ }^{15}$ It is therefore likely that the increase in the number of cells which make collagen, which are present in the liver in conditions of fibrosis, contributes to the total amount of collagen which is laid down. Our data, however, indicate that factors are present in cirrhotic or precirrhotic livers which specifically stimulate collagen production without having any effect on cell growth. It is therefore unlikely that the lymphokines reported by other groups are the same as collagen stimulating factors. A preliminary report suggested that a factor similar to collagen stimulating factor in activity was present in lymphocytes of patients with alcoholic liver disease but the influence of this factor(s) on cell growth was not examined. ${ }^{16}$

Another possible source of collagen stimulating 
factors are products derived from macrophages 1718 and so called connective tissue activating peptide. ${ }^{19}$ Since collagen stimulating factors are not present in normal liver it is unlikely that the latter compounds are similar to collagen stimulating factors.

Others have reported the presence of two factors which can be isolated from the livers of hypocholesterolaemic rats which stimulate the production of collagen in cultured fibroblasts. ${ }^{1020}$ Glutamine may be responsible for the activity of one of them..$^{1020}$ Evidence presented here shows that glutamine has only a limited effect on collagen synthesis compared with collagen stimulating factors and it is improbable that glutamine is responsible for any collagen stimulating factor activity.

In summary, the properties of collagen stimulating factors may be listed as follows: (a) they are present in mouse and human liver in conditions of acute and chronic fibrosis; (b) they specifically stimulate collagen synthesis but not non-collagen protein synthesis and they stimulate the secretion of collagen $^{4}$; (c) they are low molecular weight compounds, heat stable, and possibly peptides as judged by their sensitivity to trypsin ${ }^{4} ;(d)$ they are present in conditions of fibrosis in other tissues 12 and may therefore play a fundamental role in the tissue response to injury.

The work was partially supported by a grant from the Distillers Company, UK. Dr BC Sykes supplied the anticollagen antibody. Mrs Vera Macintosh typed the manuscript.

\section{References}

' Rojkind M, Giamborne MA, Biempica L. Collagen types in normal and cirrhotic liver. Gastroenterology 1979;7s:710-9.

${ }^{2}$ McGee J O'D, O Hare RP, Patrick RS. Stimulation of the collagen biosynthetic pathway by factors isolated from experimentally damaged liver. Nature 1973;243:121-3.

${ }^{3}$ McGee J O'D, Patrick RS, Rodger MC, Luty CM. Collagen prolyl hydroxylase activity and ${ }^{35}$-sulphate uptake in human liver biopsies. Gut 1974;15:260-7.
4 McGee J O' D, Fallon A. Hepatic cirrhosis-a collagen formative disease. J Clin Pathol 1977;31: suppl 12: 150-7.

s Peterkovsky B, Diegleman RP. The use of a mixture of proteinase free collagenase for specific assay of radioactive collagen in the presence of other proteins. Biochem J 1971;10:988-93.

${ }^{6}$ Hutton JJ Jr, Tappel AL, Udenfriend S. A rapid assay from collagen proline hydroxylase. Analyt Biochem 1966;16:384 94.

'Burton K. Determination of DNA concentration with diphenylamine. Biochem J 1956;62:315-323.

8 Zannoni V, Lynch M, Goldstein S, Salo P. A rapid micro-method for determination of ascorbic acid in plasma and tissues. Biochem Med 1974;11:41-8.

- Sykes BC, Solomon E. Assignment of type I collagen gene to human chromosome 7. Nature 1978;272:548-9.

${ }^{10}$ Ronnema T, Pellinieni TT, Kulonen E. Factors stimulating collagen synthesis from the liver of hypercholesterolaemic rats. Atherosclerosis 1976;24:311-9.

"Stassen FLH, Cardinale GJ, Udenfriend S. The activation of prolyl hydroxylase in L-929 fibroblasts by ascorbic acid. Proc Nat Acad Sci USA 1973;70:1090-3.

12 O' Hare RP, Fallon A, Bradley JF, Burns J, McGee J O' D. Isolation of collagen stimulating factors from healing wounds. $J$ Clin Pathol 1983;36:707-11.

13 Wahl SM, Wahl LM, McCarthy JB. Lymphocyte mediated activation of fibroblast proliferation and collagen production. $J$ Immunol 1978;121:942-6.

14 Johnson RL, Ziff M. Lymphocyte stimulation of collagen accumulation. J Clin Invest 1976;58:240-52.

15 Wyler DJ, Wahl SM, Wahl LM. Hepatic fibrosis in schistosomiasis: egg granulomas secrete fibroblast stimulating factor in vitro. Science 1977;202:438-40.

${ }^{16}$ Chen T, Leery CM. Collagen biosynthesis in hepatic fibrosis. Gastroenterology 1973;64:178.

${ }^{17}$ Heppleston AG, Styles JA. Activity of a macrophage factor in collagen formation by silica. Nature 1967;214:521-7.

${ }^{18}$ Allison AC, Clark IA, Davies P. Cellular interactions in fibrogenesis. Ann Rheum Dis 1977;36: suppl 8.

${ }^{19}$ Smith AF, Castor CW. Connective tissue activation XII. J Rheumatol 1979;5:177-83.

${ }^{20}$ Ronnema $T$, Vihergaa $T$, Ranta $H$. Identification of glutamine as an hepatic factor which influences the synthesis of collagen by freshly isolated fibroblasts. Scand $J$ Clin Lab Invest 1977;32:351-66.

Requests for reprints to: Professor J O' D McGee, Nuffield Department of Pathology, John Radcliffe Hospital, Level 1, Headington, Oxford OX3 9DU, England. 